\title{
Carbon monoxide distributions from the IASI/METOP mission: evaluation with other space-borne remote sensors
}

\author{
M. George ${ }^{1}$, C. Clerbaux ${ }^{1}$, D. Hurtmans ${ }^{2}$, S. Turquety ${ }^{1, *}$, P.-F. Coheur ${ }^{2}$, M. Pommier ${ }^{1}$, J. Hadji-Lazaro ${ }^{1}$,

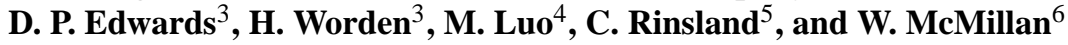 \\ ${ }^{1}$ UPMC Univ. Paris 06; Université Versailles St-Quentin; CNRS/INSU, LATMOS-IPSL, Paris, France \\ ${ }^{2}$ Spectroscopie de l'Atmosphère, Service de Chimie Quantique et Photophysique, Université Libre de Bruxelles (ULB), \\ Brussels, Belgium \\ ${ }^{3}$ Atmospheric Chemistry Division, National Center for Atmospheric Research, Boulder, Colorado, USA \\ ${ }^{4}$ Jet Propulsion Laboratory, California Institute of Technology, Pasadena, California, USA \\ ${ }^{5}$ NASA Langley Research Center, Hampton, Virginia, USA \\ ${ }^{6}$ Center for Satellite Applications and Research, National Environmental Satellite, Data and Information Service, NOAA, \\ Camp Springs, Maryland, USA \\ *now at: UPMC Univ. Paris 06; LMD/IPSL, Ecole Polytechnique, Palaiseau, France
}

Received: 24 February 2009 - Published in Atmos. Chem. Phys. Discuss.: 17 April 2009

Revised: 20 October 2009 - Accepted: 20 October 2009 - Published: 3 November 2009

\begin{abstract}
The Infrared Atmospheric Sounding Interferometer (IASI) onboard the MetOp satellite measures carbon monoxide $(\mathrm{CO})$ on a global scale, twice a day. $\mathrm{CO}$ total columns and vertical profiles are retrieved in near real time from the nadir radiance spectra measured by the instrument in the thermal infrared (TIR) spectral range. This paper describes the measurement vertical sensitivity and provides a first assessment of the capabilities of IASI to measure $\mathrm{CO}$ distributions. On the global scale, 0.8 to 2.4 independent pieces of information are available for the retrieval. At mid latitudes, the information ranges between 1.5 and 2, which enables the lower and upper troposphere to be distinguished, especially when thermal contrast is significant. Global distributions of column $\mathrm{CO}$ are evaluated with correlative observations available from other nadir looking TIR missions currently in operation: the Measurements of Pollution in the Troposphere (MOPITT) onboard TERRA, the Atmospheric Infrared Sounder (AIRS) onboard AQUA and the Tropospheric Emission Spectrometer (TES) onboard AURA. The IASI CO columns are compared with MOPITT, AIRS and TES CO columns, adjusted with the a priori, for three different months: August 2008, November 2008 and February 2009. On average, total column discrepancies of about $7 \%$ are found between IASI and the three other sounders in the
\end{abstract}

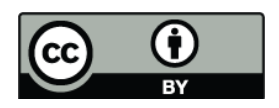

Correspondence to: M. George (maya.george@latmos.ipsl.fr)
Northern Hemisphere and in the equatorial region. However when strong $\mathrm{CO}$ concentrations are present, such as during fire events, these discrepancies can climb as high as $17 \%$. Instrument specifications of IASI versus other missions are also discussed.

\section{Introduction}

As one of the most important precursors of ozone $\left(\mathrm{O}_{3}\right)$, carbon monoxide (CO) is an important trace gas for the understanding of both air quality and climate forcing. Formed by the incomplete combustion of fossil and bio-fuels, and by vegetation burning, $\mathrm{CO}$ is also produced in the atmosphere via the oxidation of methane and non-methane hydrocarbons by the hydroxyl radical $(\mathrm{OH})$ (Duncan et al., 2008). It is the largest global sink of the $\mathrm{OH}$ radical and thus plays an important role in the oxidizing power of the atmosphere and in the concentrations of greenhouse gases such as methane and $\mathrm{O}_{3}$. Because of its relatively long lifetime (a few weeks to a few months depending on latitude and time of year), $\mathrm{CO}$ has been extensively used as an atmospheric tracer of transport (Logan et al., 1981).

$\mathrm{CO}$ is routinely measured by ground-station networks (Kurylo, 1991; Pougachev and Rinsland, 1995; Novelli et al., 1998; Yurganov et al., 2004, 2005; Velazco et al., 2007; Zander et al., 2008), airborne measurement campaigns, airborne

Published by Copernicus Publications on behalf of the European Geosciences Union. 
networks (Nedelec et al., 2005) and by instruments onboard satellites. In recent years, extensive $\mathrm{CO}$ observations from space, from a number of satellite platforms, have yielded a global view of the $\mathrm{CO}$ distribution, from the troposphere to the mesosphere. Limb-sounders (in absorption or emission) can derive vertically resolved profiles for the mid/hightroposphere and higher, with a limited spatial coverage, e.g. SMR/ODIN (Barret et al., 2006), MIPAS/ENVISAT (Funke et al., 2007), MLS/AURA (Pumphrey et al., 2007; Livesey et al., 2008) and ACE-FTS/SCISAT-1 (Clerbaux et al., 2008a). Nadir viewing remote sensors offer the advantage of sounding into the lower atmosphere, although with a limited vertical resolution, as was demonstrated from MOPITT/TERRA (Deeter et al., 2003; Edwards et al., 2004), SCIAMACHY (Buchwitz et al., 2004, 2007; de Laat et al., 2006, 2007; Frankenberg et al., 2005), TES/AURA (Rinsland et al., 2006; Luo et al., 2007a and b), AIRS/AQUA (McMillan et al., 2005), and IASI/MetOp (Turquety et al., 2004; Clerbaux et al., 2009). Both nadir viewing and limb viewing instruments are often impacted by the presence of clouds. Time series of $\mathrm{CO}$ measurements show the impact of inter-annual variations, for example a moderate El Niño event in 2006 (Rinsland et al., 2008).

Validation of satellite CO retrievals with space-borne, airborne or ground-based measurements has already been performed in the frame of different exercises or campaigns (Clerbaux et al., 2002, 2008a; Emmons et al., 2004, 2007, 2009; Warner et al., 2007; Luo et al., 2007a and b; Yurganov et al., 2008). In this paper, we focus on the analysis of global $\mathrm{CO}$ distributions recently calculated from the radiance spectra recorded by the IASI instrument. A case study of the Mediterranean fires during the summer of 2007, which illustrates the capability of IASI to measure extreme $\mathrm{CO}$ concentrations and to track the plume from wildfires, is presented in a companion paper (Turquety et al., 2009). Here we compare the IASI global distributions with $\mathrm{CO}$ observations available from other nadir looking instruments which also record surface and atmospheric signals in the thermal infrared (TIR) spectral range: MOPITT, AIRS and TES. The paper presents a preliminary and non exhaustive validation exercise. It is focused on the $\mathrm{CO}$ total column products obtained with the FORLI-CO retrieval code in near real time. Basic theoretical elements of the software are provided but for a more in-depth description on the $\mathrm{CO}$ radiative transfer and retrieval algorithm we rather refer to Turquety et al. (2009) and Hurtmans et al. (2009).

The comparison is performed on monthly averaged $\mathrm{CO}$ data for three months, August 2008, November 2008, and February 2009. In order to take into account the different a priori used for $\mathrm{CO}$ retrieval by each instrument, we have followed the method suggested by Rodgers and Connor (2003) and Luo et al. (2007a). The columns have been adjusted according to the a priori used by the different teams. A full treatment that takes into account the averaging kernels (Rodgers and Connor, 2003) is presented for TES and IASI, the two instruments with the largest differences in terms of vertical resolution.

The paper is organized as follows: First we describe the IASI-CO measurements as routinely retrieved from the operational Eumetsat radiance products. Next we compare the CO total column distributions retrieved by MOPITT, AIRS and TES data for August 2008, November 2008 and February 2009. And finally we conclude with an analysis of the observed agreement and discrepancy.

\section{IASI: CO column and profile retrievals}

\subsection{The IASI mission}

The polar-orbiting MetOp-A, launched on 19 October 2006, is the first of three successive MetOp satellites. As a component of the space segment of the Eumetsat Polar System (EPS), this operational meteorological platform carries the IASI instrument, a nadir-looking high resolution Fourier Transform Spectrometer (FTS). IASI is designed to provide atmospheric temperature and water vapour profiles for operational meteorology. Owing to its apodized spectral resolution of $0.5 \mathrm{~cm}^{-1}$ (with a spectral sampling of $0.25 \mathrm{~cm}^{-1}$ ), its extended spectral range (from 645 to $2760 \mathrm{~cm}^{-1}$ with no gaps), and its low radiometric noise (from on-flight analysis the Noise Equivalent Delta Temperature, NEDT, is estimated to range from 0.1 to $0.4 \mathrm{~K}$; Clerbaux et al., 2009), atmospheric concentrations for several key species important to climate forcing and atmospheric chemistry monitoring can be derived from IASI radiance measurements. Such species include not only the predominant $\mathrm{CO}$ (Turquety et al., 2009), $\mathrm{O}_{3}$ (Boynard et al., 2009), $\mathrm{CH}_{4}$ (Razavi et al., 2009), $\mathrm{HNO}_{3}$ (Wespes et al., 2009) molecules but also weakly absorbing molecules detected during extraordinary events, such as $\mathrm{SO}_{2}$ during volcanic eruption (Clarisse et al., 2008) or reactive species in fire plumes (Coheur et al., 2009). In addition, IASI offers an excellent horizontal coverage due to its across track swath width of $2200 \mathrm{~km}$, allowing global coverage twice a day, with a field of view sampled by $2 \times 2$ circular pixels each with a $12 \mathrm{~km}$ footprint diameter.

\subsection{CO retrievals}

$\mathrm{CO}$ distributions are retrieved from IASI radiance spectra using a dedicated software, FORLI-CO, developed at Université Libre de Bruxelles (ULB) to handle as fast as possible all the IASI spectra, i.e. 1.3 millions of observations per day, dissiminated through the Eumetsat data distribution system Eumetcast about $3 \mathrm{~h}$ after observation. The code is based on the validated Atmosphit software (Barret et al., 2005; Coheur et al., 2005), but instead of using line-by-line calculations, the FORLI radiative transfer uses pre-calculated tables of absorbances at various pressure and temperature, in the spectral region of the CO 1-0 band. The code can accommodate temperature and humidity profiles coming from various 

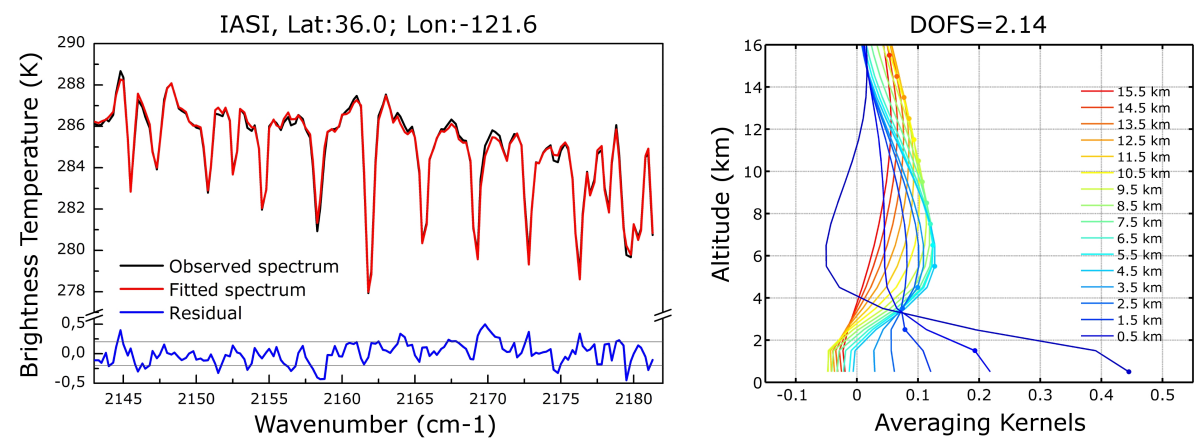

Fig. 1. Left panel: Spectral range used for the FORLI-CO retrieval. The spectrum (in brightness temperature units) was recorded around 09:30 local time, on 1 August 2008, close to Los Angeles (USA). The residual difference (blue) between the measured spectrum (black) and the calculated spectrum (red) is within the IASI radiometric noise $(0.2 \mathrm{~K})$. Right panel: FORLI-CO averaging kernels functions, for the same observation, for different merged vertical layers.

sources/models, including the operational MetOp Level 2 meteorogical products (Schluessel et al., 2005). These Level 2 products are validated, although some issues remain for water vapour (see Zhou et al., 2008 and Pougatchev et al., 2009).

Figure 1 illustrates, in equivalent brightness temperatures, the IASI spectral range that is used for the $\mathrm{CO}$ retrieval $\left(2143-2181.25 \mathrm{~cm}^{-1}\right)$. It was chosen in order to avoid most of the other absorbing species in the $\mathrm{CO}$ spectral range (i.e. $\mathrm{H}_{2} \mathrm{O}, \mathrm{O}_{3}, \mathrm{CO}_{2}$ and $\mathrm{N}_{2} \mathrm{O}$ ). The plot also shows the (observed - calculated) residual after the retrieval for an observation (located over the West coast of the USA), which can be directly compared with the IASI radiometric noise level.

FORLI-CO provides CO profiles for at most 19 layers (from the surface to the top of the atmosphere). The retrieval scheme is based on the Optimal Estimation Method (OEM) described by Rodgers (2000). Given a measurement $y$ (IASI radiance spectra), with error covariance $\mathrm{S}_{\varepsilon}$ and a forward model $\hat{y}=F(\boldsymbol{x})$, the OEM then seeks the optimal solution for the state vector $\boldsymbol{x}$ (CO profile) to be retrieved. Since more than one solution could fit the observations (ill-posed problem), it is necessary to constrain the results with a priori information containing both the averaged value expected, $\boldsymbol{x}_{a}$ and allowed variability around this average given by a covariance matrix $\mathbf{S}_{a}$. The solution can be found by iteratively applying:

$\hat{\boldsymbol{x}}_{i+1}=\boldsymbol{x}_{a}+\mathbf{D}_{y}\left[y-F\left(\hat{\boldsymbol{x}}_{i}\right)-\mathbf{K}_{i}\left(\boldsymbol{x}_{a}-\hat{\boldsymbol{x}}_{i}\right)\right]$

with $\mathbf{D}_{y}=\hat{\mathbf{S}}_{i} \mathbf{K}_{i}^{T} \mathbf{S}_{\varepsilon}^{-1}$ and $\hat{\mathbf{S}}_{i+1}=\left(\mathbf{K}_{i+1}^{T} \mathbf{S}_{\varepsilon}^{-1} \mathbf{K}_{i+1}+\mathbf{S}_{a}^{-1}\right)^{-1}$ where $\mathbf{K}_{i}=\left(\frac{\delta F}{\delta \boldsymbol{x}}\right)_{i}$ is the Jacobian at state $\boldsymbol{x}_{i}, \mathbf{K}_{i}^{T}$ is its transpose, and $\hat{\boldsymbol{x}}_{i+1}$ is the updated state vector. The matrix $\mathbf{D}_{y}$ is known as the matrix of contribution functions. The error covariance of the solution is given by $\hat{\mathbf{S}}_{i+1}$. The iteration starts with some initial estimate of the state, chosen to be the a priori information $\boldsymbol{x}_{a}$, of covariance $\mathbf{S}_{a}$, and terminates when convergence has been reached. An important element for the retrievals in the thermal infrared is the choice of the prior information. Here the a priori mean profile and associated variance-covariance matrix were constructed using a database of observations that included aircraft profiles from the MOZAIC (Measurement of OZone and water vapour by AIrbus in-service air-Craft) program (Nedelec et al., 2003), and ACE-FTS satellite observations in the upper troposphere and above (Clerbaux et al., 2005). These were complemented with distributions from the LMDz-INCA global model (Turquety et al., 2008) in order to build a matrix representative of both background and polluted conditions.

The characterization of the retrieved products also uses the optimal estimation formalism; diagnostic tools therefore include retrieval errors from various sources (smoothing, measurements) and averaging kernels. The latter (see Fig. 1 for an example of IASI averaging kernels) characterize the sensitivity of each measurement to the true $\mathrm{CO}$ profile, with the remainder of the information provided by the a priori profile:

$\hat{\boldsymbol{x}}=\mathbf{A} \boldsymbol{x}+(\mathbf{I}-\mathbf{A}) \boldsymbol{x}_{a}$

with $\hat{\boldsymbol{x}}$ the retrieved profile, $\mathbf{A}$ the averaging kernels matrix, $\boldsymbol{x}$ the true profile and $\boldsymbol{x}_{a}$ the a priori profile. The rows of the averaging kernel matrix describe the change to the retrieval state at a specific altitude to a perturbation of the true state vector and provide an estimation of the vertical resolution (full width at half maximum). The trace of the matrix, known as the degrees of freedom for signal (DOFS), is a metric used to measure the number of independent pieces of information available from the retrieval (Rodgers, 2000). In the example presented in Fig. 1, the set of averaging kernels presents two maxima (at the surface and around $6 \mathrm{~km}$ ) and the DOFS number is 2.14. As described in previous papers (e.g. Deeter et al., 2007; Clerbaux et al., 2008b, 2009) the thermal contrast (i.e. the temperature difference between the surface and the first atmospheric layer) is a critical parameter for the understanding of the vertical information contained in the $\mathrm{CO}$ product. For the example described here, the measurement is performed at a location associated with a large thermal contrast (close to Los Angeles, USA, morning orbit) and hence 


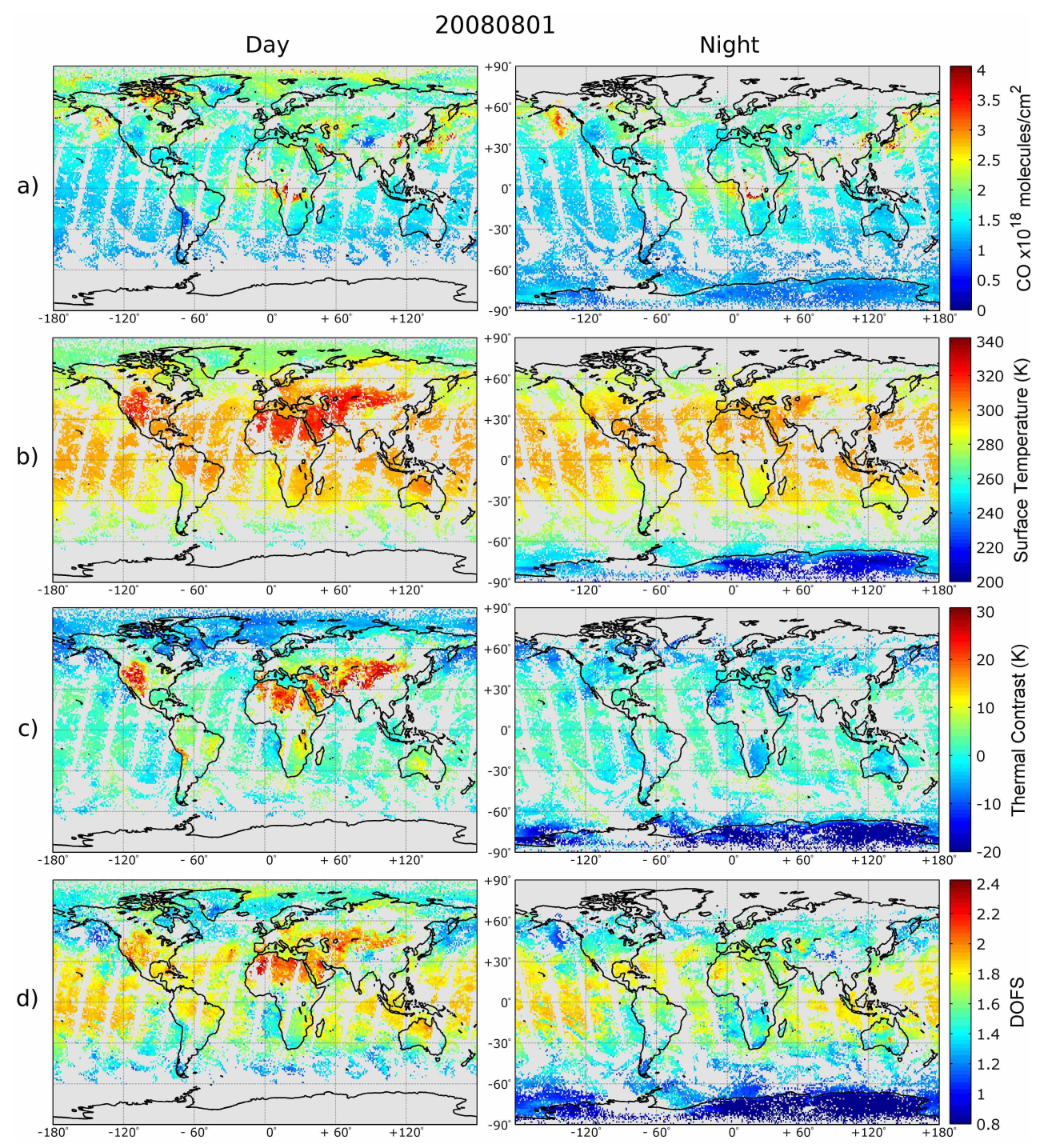

Fig. 2. IASI global distributions on 1 August 2008, for daytime (left) and night time (right). Cloud free observations are binned on a $0.5^{\circ} \times 0.5^{\circ}$ grid. (a) CO total column distribution as retrieved by FORLI-CO. (b) Surface temperature (available from Eumetsat). (c) Thermal contrast as calculated from the difference between surface temperature and the temperature of the first available level of temperature profile. (d) Degrees of freedom of the signal (DOFS) as calculated from the averaging kernel matrices.

the averaging kernels corresponding to the lower layers exhibit large sensitivity at the surface. Two independent partial columns can be retrieved for that observation, allowing the separation of the $\mathrm{CO}$ concentration in the boundary layer from the mid troposphere. It is worth noting that for other atmospheric conditions, where the thermal contrast is less significant, there is no sensitivity at the surface.

Typically, with the computational power in place at ULB (76 CPUs), the full procedure of ray-tracing, radiative transfer calculations and iterative retrievals allows treating IASI data in near-real-time, only one hour after reception through Eumetcast; thus four hours after the recorded observation. For the study presented here, only cloud free data (see Clerbaux et al., 2009, Sect. 3.2.1) are analysed. Figure 2 il- lustrates one day (1 August 2008) of IASI CO observations, both for day and night measurements, along with the corresponding surface temperature from IASI Level 2 data, thermal contrast (as calculated from the difference between surface temperature and the temperature of the first available atmospheric level), and DOFS. As expected, differences appear between day and night distributions, which can be linked directly to the thermal contrast, which is much more pronounced during the day than during the night. This reflects onto the DOFS numbers that are larger over areas where the thermal contrast exceeds a few degrees. On the global scale, DOFS values range between 0.8 and 2.4, for this specific day, but these values are also representative for other time periods. Generally, for latitudes above $60^{\circ} \mathrm{N}$ and 
Table 1. Description of current missions and instruments that measure tropospheric CO from nadir TIR radiances. All missions are on polar sun-synchronous orbiting platforms. Specifications are given for the CO thermal IR spectral range only, and for the nadir geometry.

\begin{tabular}{|c|c|c|c|}
\hline $\begin{array}{l}\text { Mission/Plate-form } \\
\text { Agency } \\
\text { Launch date } \\
\text { Data (L1) availability }\end{array}$ & $\begin{array}{l}\text { Plate-form altitude } \\
\text { Equator crossing time, descend- } \\
\text { ing/ascending orbit } \\
\text { Instrument type }\end{array}$ & $\begin{array}{l}\text { Spectral coverage }\left(\mathrm{cm}^{-1}\right) \\
\text { Pixel size, Spatial coverage } \\
\text { Spectral resolution } \\
\text { Radiometric precision for CO lines } \\
\text { (NeDT@ 280K) }\end{array}$ & References \\
\hline $\begin{array}{l}\text { IASI/MetOp } \\
\text { EUMETSAT/CNES } \\
\text { October } 2006 \\
\text { May } 2007\end{array}$ & $\begin{array}{l}817 \mathrm{~km} \\
09: 30, \mathrm{~d} \\
\text { FTS, } 8461 \text { channels, OPD } 2 \mathrm{~cm}\end{array}$ & 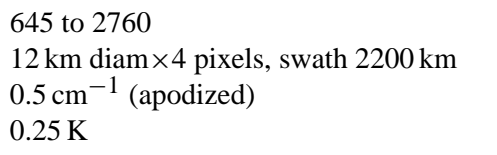 & $\begin{array}{l}\text { Schluessel et al., } 2005 \\
\text { Turquety et al., } 2004 \\
\text { Clerbaux et al., 2007, } 2009\end{array}$ \\
\hline $\begin{array}{l}\text { MOPITT/TERRA } \\
\text { NASA (EOS) } \\
\text { December } 1999 \\
\text { March } 2000\end{array}$ & $\begin{array}{l}705 \mathrm{~km} \\
10: 30, \mathrm{~d} \\
\text { Gas correlation radiometer, } 3 \text { bands, } \\
8 \text { channels }\end{array}$ & $\begin{array}{l}2140-2192,4265-4305 \\
22 \times 22 \mathrm{~km}, \text { swath } 640 \mathrm{~km} \\
0.04 \mathrm{~cm}^{-1} \text { (effective) } \\
0.05 \mathrm{~K}\end{array}$ & $\begin{array}{l}\text { Drummond, } 1989 \\
\text { Edwards et al., } 2004 \\
\text { Deeter et al., 2003, } 2007\end{array}$ \\
\hline $\begin{array}{l}\text { AIRS/AQUA } \\
\text { NASA (EOS) } \\
\text { May } 2002 \\
\text { August } 2002\end{array}$ & $\begin{array}{l}705 \mathrm{~km} \\
13: 30, \text { a } \\
\text { Grating spectrometer, } 2378 \text { channels, } \\
\text { resolving power } \lambda / \Delta \lambda=1200\end{array}$ & $\begin{array}{l}650-1136,1216-1613,2170-2674 \\
13.5 \times 13.5 \mathrm{~km} \times 9 \text { pixels, swath } 1650 \mathrm{~km} \\
\sim 1.8 \mathrm{~cm}^{-1}\left(2170-2200 \mathrm{~cm}^{-1}\right) \\
0.14 \mathrm{~K}\end{array}$ & $\begin{array}{l}\text { McMillan et al., 2005, } 2008 \\
\text { Aumann et al., } 2003\end{array}$ \\
\hline $\begin{array}{l}\text { TES/AURA } \\
\text { NASA (EOS) } \\
\text { July } 2004 \\
\text { August } 2004\end{array}$ & $\begin{array}{l}705 \mathrm{~km} \\
10: 45 \text {, a } \\
\text { FTS, } 40540 \text { channels, OPD } 8.45 \mathrm{~cm}\end{array}$ & $\begin{array}{l}652-919(2 \mathrm{~B} 1), 923-1160(1 \mathrm{~B} 2), 1090- \\
1339(2 \mathrm{~A} 1) \text { and } 1891-2251(1 \mathrm{~A} 1) \\
0.53 \times 8.3 \mathrm{~km} \times 16 \text { pixels } \\
0.10 \mathrm{~cm}^{-1} \text { (apodized) } \\
1.5 \mathrm{~K}(@ 300 \mathrm{~K})\end{array}$ & $\begin{array}{l}\text { Beer et al., } 2006 \\
\text { Bowman et al., } 2006 \\
\text { Rinsland et al., } 2006 \\
\text { Luo et al., 2007a and b } \\
\text { Worden et al., } 2006\end{array}$ \\
\hline
\end{tabular}

below $60^{\circ} \mathrm{S}$ only a total column (DOFS around 1) can be retrieved. At mid latitudes, the information ranges between 1.5 and 2, allowing the lower and upper troposphere to be distinguished. For very cold areas, e.g. Antarctic during the night, the retrieval profile consists merely of the a priori profile. On the contrary, for hot locations during the day, the DOFS can provide two pieces of independent information and the retrievals are much less weighted by the a priori.

\section{CO correlative measurements distribution}

In order to evaluate the FORLI-CO results we use similar products available from other currently operational nadir looking TIR instruments: MOPITT, AIRS and TES. A general description of the different missions and instrument specifications is provided in Table 1 .

In the following sections, we present briefly the retrieval methods and the a priori of each instrument. The different spectral resolutions and vertical sensitivities are also discussed. We then focus on comparison of monthly averaged total column $\mathrm{CO}$ distributions for three months at different seasons, in order to derive general trends in terms of discrepancies.
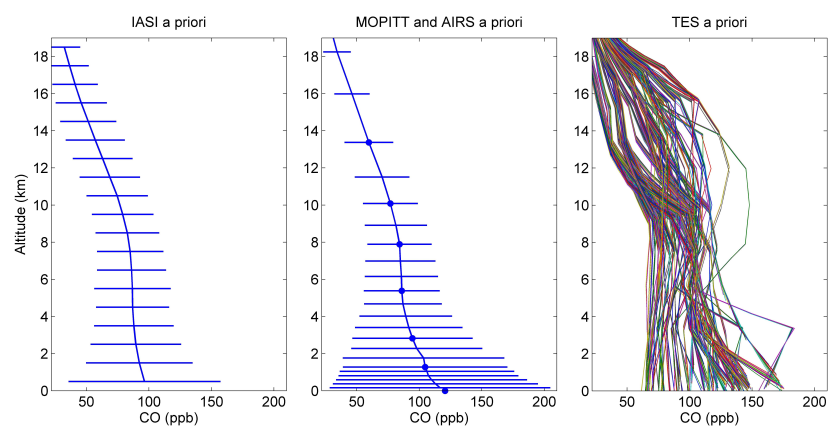

Fig. 3. A priori profiles and standard deviations used in the different retrievals: IASI (left), MOPITT and AIRS (middle) and TES for August (right). For IASI and MOPITT, the standard deviations are from the diagonal elements of the a priori covariance matrix $\mathbf{S}_{a}$. MOPITT V3 retrievals use the mean profile and covariance matrix values at the seven levels shown by the blue dots. AIRS V5 retrievals do not employ a covariance of the a priori. TES a priori profiles vary in time and location (monthly, $10^{\circ}$ lat $\times 60^{\circ}$ lon blocks), and only the profiles for the August climatology are presented here. See Fig. 6 in Luo et al. (2007a) for a representation of $\mathbf{S}_{a}$ for TES. 

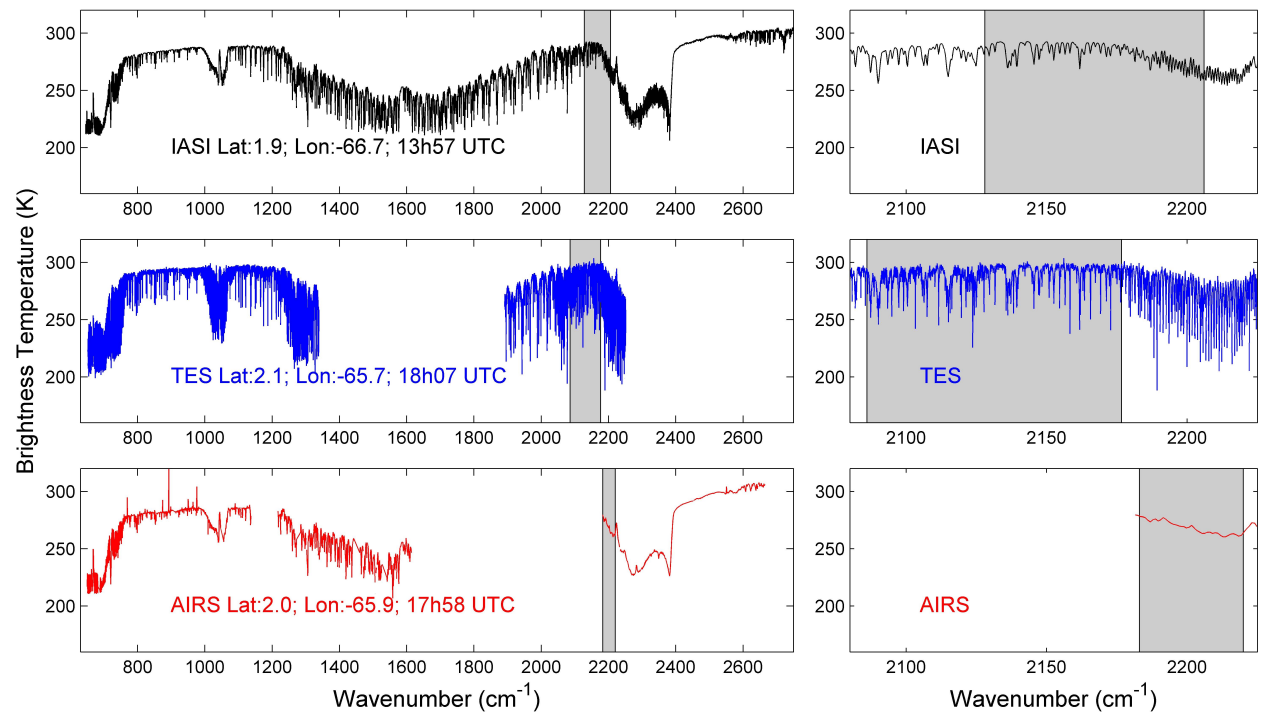

Fig. 4. IASI, TES and AIRS radiance spectra (in brightness temperature) around Northern Brazil, on 1 August 2008. The spectral range used for the CO retrieval are highlighted in grey. For the full spectral range covered by each on the left and zoomed for the CO window on the right (IASI [2143 2181.25]; TES [2086.06 2176.66] and AIRS [2181.49 2221.12]).

\subsection{Retrieval methods and a priori}

\subsubsection{MOPITT}

MOPITT uses correlation radiometry (Drummond, 1989) and the terrestrial thermal emission to sound tropospheric CO. More recently, it was also shown that the solar channels provide supplementary information (Deeter et al., 2009). $\mathrm{CO}$ retrievals are obtained by using a maximum a posteriori method that incorporates a priori information of the physical and statistical variability of the trace gas distribution in the atmosphere (Pan et al., 1998). For this study we use MOPITT V3 data which are filtered for clouds. This version uses a single $\mathrm{CO}$ a priori profile and the covariance matrix is derived from several hundred in situ $\mathrm{CO}$ data distributed globally (Deeter et al., 2003) (Fig. 3). It is worth noting that MOPITT V4 products (that were not available at the time of this study) include log-normal statistics for VMR, a modified forward model that handles extreme pollution conditions, and variable a priori profiles. Differences between the global a priori profile used in V3 and the geographically and temporally variable a priori profiles used in V4 might lead to significant differences in $\mathrm{CO}$ total column values.

\subsubsection{TES}

TES nadir Global Survey (GS) observations consist of 16 orbits in a $26 \mathrm{~h}$ period; a new GS starts every other day. The along orbit observations are made approximately every $180 \mathrm{~km}$. The TES CO prior information is derived from a year of simulation with the MOZART model (Brasseur et al., 1998). The prior profiles are monthly means in blocks of $10^{\circ} \times 60^{\circ}$ (latitude by longitude) (See Fig. 3, for August) TES CO retrievals apply modified Tikhanov constraints $(\mathrm{Ku}-$ lawik et al., 2008). Spectral micro windows with isolated CO lines are used in CO retrievals (Rinsland et al., 2006). Here we use TES V004 GS data. Data quality and cloud filtering criteria are used to select TES CO total columns according to TES Level 2 Data User's Guide (Osterman et al., 2008).

\subsubsection{AIRS}

Tropospheric CO abundances are retrieved from AIRS cloudcleared radiances, utilizing a set of overlapping trapezoidal perturbation functions, similar to the retrieval of all AIRS products (Susskind et al., 2003). Version 5 (V5) AIRS CO retrievals used in this analysis differ from the V4 products used in previous studies (McMillan et al., 2005 and 2008; Warner et al., 2007; Yurganov et al., 2008) in terms of the number of trapezoidal functions and the first guess profile. V5 employs the MOPITT V3 a priori profile as a single global first guess profile (see Fig. 3) with nine trapezoidal perturbation functions (Comer, 2006). The lowest of these nine functions were chosen to closely coincide with the seven reporting levels for MOPITT CO retrievals. Overall, the nine functions better define the shape of the AIRS CO averaging kernels verses the V4 four trapezoidal functions described in McMillan et al. (2008). The nine functions represent coarse supersets of the AIRS 100 layer radiative transfer model. The largest DOFS numbers are 1.5 in AIRS CO retrievals, but typical values are closer to 0.8 . For this study, AIRS V5 data were accessed through the NASA Goddard DAAC and filtered with Qual_CO $=0$, CloudFrcStd $<=0.8$, TSurfStd $=>250 \mathrm{~K}$ and (PSurfStd - Pbest $)<200 \mathrm{mb}$. 


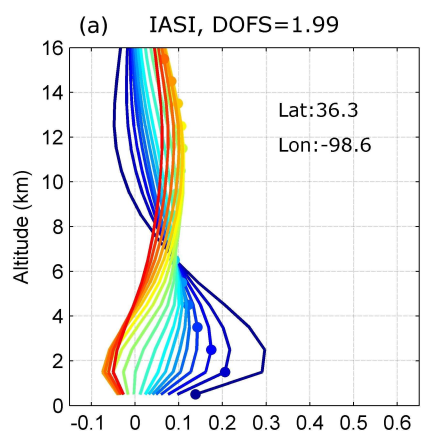

(b) MOPITT, DOFS $=1.58$
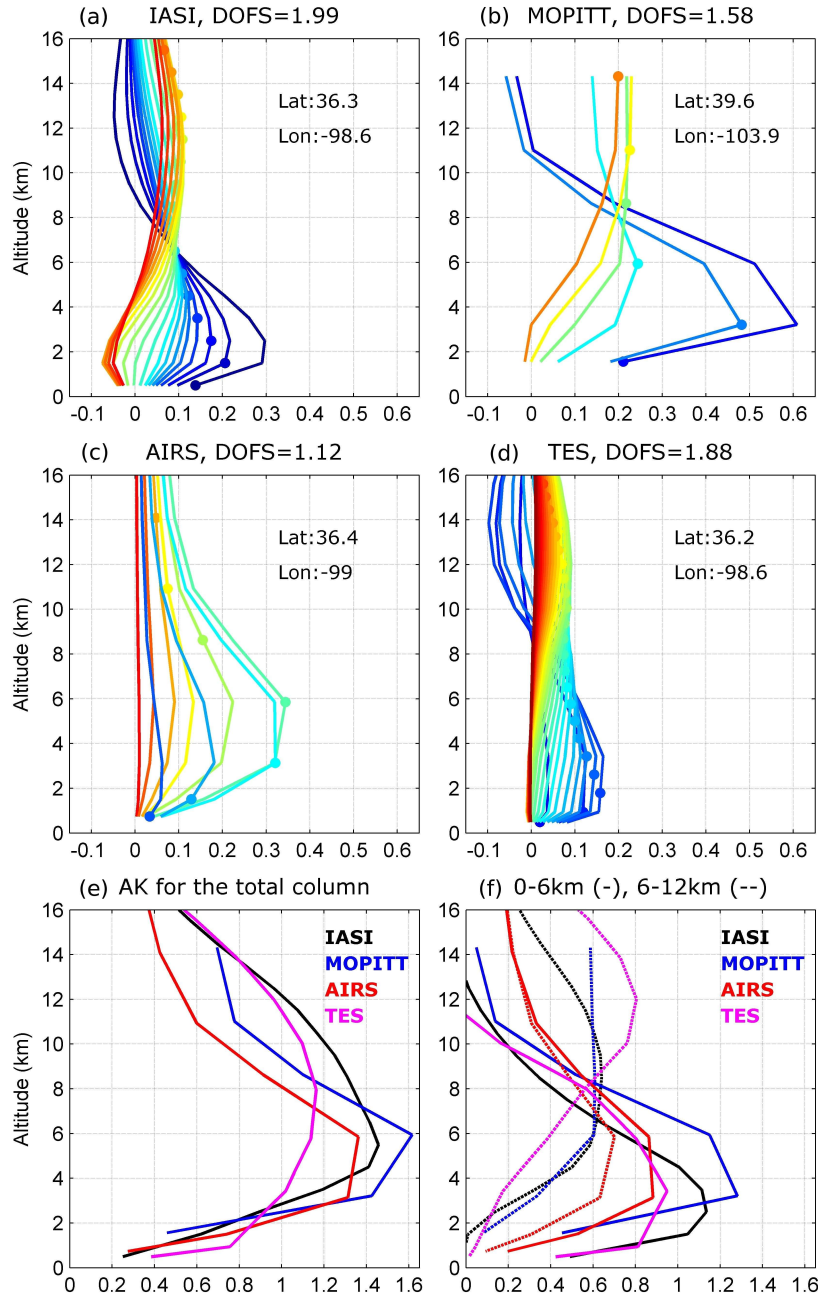

(d) TES, DOFS $=1.88$

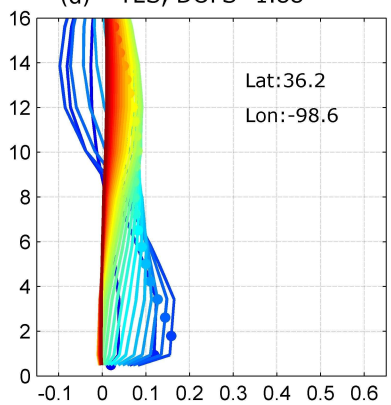

(f) $0-6 \mathrm{~km}(-), 6-12 \mathrm{~km} \mathrm{(--)}$

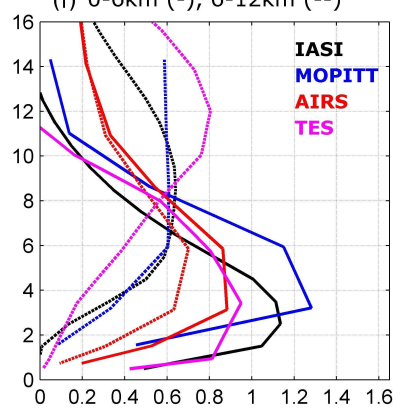

IASI in terms of spectral coverage. As MOPITT is a gas correlation radiometer, the radiance signal is not directly comparable.

Figure 5 illustrates the averaging kernel functions for IASI, MOPITT, AIRS and TES at another coincident observation (over the USA). For each instrument, the raw averaging kernel matrix provided by each team at the different retrieved levels is plotted in Fig. 5a, b, c and d. The functions have similar shapes, with low sensitivity near the surface and maximum sensitivity in the low troposphere (4$6 \mathrm{~km}$ ), which highlight more the dependencies of the infrared nadir observation to the geophysical scene rather than to the instrument performance. The number of retrieved altitude levels differs markedly for each instrument (IASI $=19$, MOPITT $=7$, AIRS $=9$, TES =67) and is not representative of the vertical resolution. This also explains the different absolute values of the averaging kernels, with higher peak values for thicker layers. For the four instruments, the DOFS are larger than 1, illustrating that the information of the total column comes from more than one layer of the atmosphere. Figure $5 \mathrm{e}$ presents the averaging kernel functions corresponding to total columns. For this specific observation, TES is closest to ideal (i.e. closest to 1 on all vertical levels) while the other instruments show important positive deviations in the free troposphere. In Fig. 5f we plotted the averaging kernels for the $[0-6 \mathrm{~km}]$ and $[6-12 \mathrm{~km}]$ partials columns. These two partial columns correspond to the two independent atmospheric layers usually identified for IASI or TES, and not accessible from AIRS. In general it is worth noting that the comparison of such averaging kernel functions and DOFS numbers is indicative but not quantitative as the a priori and the retrieval methods are different.

Fig. 5. Averaging kernel matrices and DOFS provided by each retrieval team for IASI (a), MOPITT (b), AIRS (c) and TES (d), for a coincident observation around $36^{\circ} \mathrm{N}-98^{\circ} \mathrm{W}$, on 1 August 2008 . Each coloured line corresponds to the altitude indicated by the coloured dot. The averaging kernels depend on vertical grid spacing, which is different for each instrument. The suplots (e) and (f) provide the averaging kernels corresponding to total columns and to [0-6 km, plain line] and [6-12 km, dashed line] partial columns.

\subsection{Spectral resolution and vertical sensitivity}

Spectra recorded above the same area by the three spectrometer type instruments, IASI, TES and AIRS, are presented in Fig. 4, for the full spectral range covered by each device (see Table 1). On the right part of the plot, an enlargement is shown with the spectral window used for the $\mathrm{CO}$ retrieval (different for each mission). The data correspond to nadir along track observations only (North Brazil), which explains the relative poor coincidence criteria, and the time of recording differs by a few hours at maximum. From these plots the TES higher spectral resolution is well marked, as are the advantages of AIRS in terms of signal to noise ratio and of

\subsection{Comparison of CO total column on the global scale}

The comparison is performed on cloud-free monthly averaged data, over a $1^{\circ} \times 1^{\circ}$ grid, in order to lower the differences associated with the different temporal and spatial ranges of each satellite. Only daytime observations are shown here.

\subsubsection{Direct comparison for August 2008 distributions}

Figure 6 presents the $\mathrm{CO}$ total column global scale distribution retrieved from IASI, MOPITT, AIRS and TES data available for August 2008. August is an interesting period to observe high $\mathrm{CO}$ concentrations in Africa due to intensive agriculture fires. A good agreement is found between the four distributions, with $\mathrm{CO}$ total column values ranging from $4 \times 10^{17}$, molecules $/ \mathrm{cm}^{2}$ (background level) to more than $4 \times 10^{18}$ molecules $/ \mathrm{cm}^{2}$ (fire events), though the IASI background data are lower than those associated with the other distributions. IASI and AIRS results have the best horizontal coverage. The largest concentrations are observed by all four instruments, although with different magnitude, over China (pollution), Africa and South America 

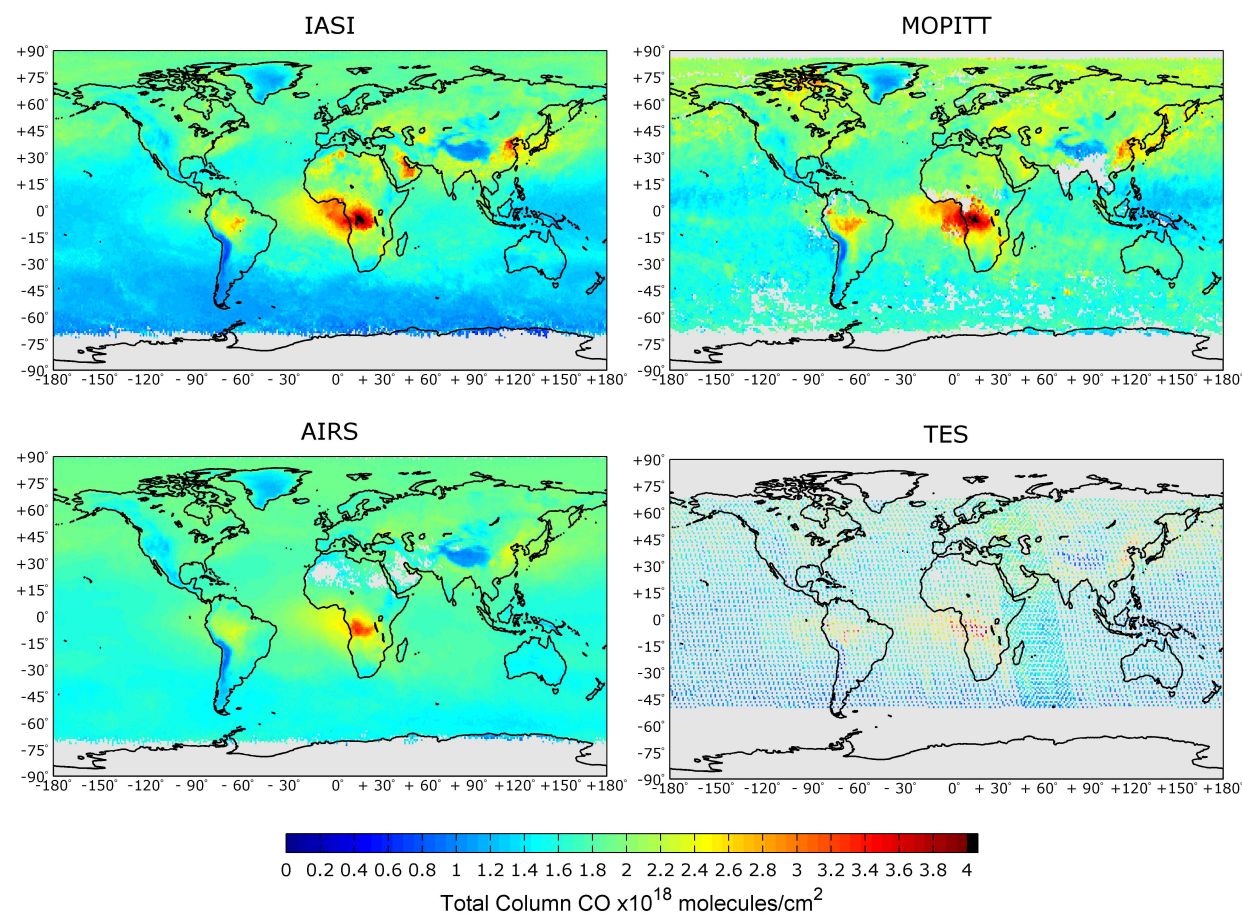

Fig. 6. Averaged IASI, MOPITT, AIRS and TES CO total column distributions, binned on a $1^{\circ} \times 1^{\circ}$ grid, for August 2008 . All observations are for day-time, and were cloud-filtered following the recommendation provided by each retrieval team. There are more TES data between $30^{\circ} \mathrm{E}$ and $90^{\circ} \mathrm{E}$ because data are recorded every 2 days for $26 \mathrm{~h}$.

Table 2. Correlation coefficients for August 2008 (see associated scatter plots in Fig. 7), November 2008 and February 2009. The IASI total columns are adjusted with the MOPITT, AIRS or TES a priori. The coefficients corresponding to the comparison of IASI total columns with TES total columns smoothed by IASI averaging kernel functions are shown in italic.

\begin{tabular}{|c|c|c|c|c|c|c|c|c|c|c|c|c|}
\hline & \multicolumn{4}{|c|}{ MOPITT } & \multicolumn{4}{|c|}{ AIRS } & \multicolumn{4}{|c|}{ TES [smoothed by AK IASI] } \\
\hline & & Aug 08 & Nov 08 & Feb 09 & & Aug 08 & Nov 08 & Feb 09 & & Aug 08 & Nov 08 & Feb 09 \\
\hline \multirow[t]{3}{*}{ Global } & Corr. coeff. & 0.83 & 0.87 & 0.92 & Corr. coeff. & 0.92 & 0.91 & 0.94 & Corr. coeff. & $0.84[0.84]$ & $0.79[0.81]$ & $0.88[0.82]$ \\
\hline & Slope & 0.92 & 0.84 & 0.83 & Slope & 1.67 & 1.45 & 1.46 & Slope & $0.88[0.84]$ & $0.86[0.84]$ & $0.95[1.01]$ \\
\hline & Intercept & -0.01 & 0.08 & 1.16 & Intercept & -1.25 & -0.91 & -0.92 & Intercept & $0.27[0.37]$ & $0.28[0.38]$ & $0.23[0.22]$ \\
\hline \multirow[t]{3}{*}{ Lat $\left[45^{\circ}, 90^{\circ}\right]$} & Corr. coeff. & 0.69 & 0.66 & 0.73 & Corr. coeff. & 0.88 & 0.85 & 0.85 & Corr. coeff. & $0.57[0.59]$ & $0.40[0.51]$ & $0.41[0.36]$ \\
\hline & Slope & 0.57 & 0.43 & 0.47 & Slope & 1.29 & 1.13 & 1.10 & Slope & $0.49[0.44]$ & $0.27[0.33]$ & $0.28[0.25]$ \\
\hline & Intercept & 0.74 & 0.83 & 0.96 & Intercept & -0.48 & -0.36 & -0.21 & Intercept & $1.02[1.12]$ & $1.40[1.31]$ & $1.66[1.81]$ \\
\hline \multirow[t]{3}{*}{ Lat $\left[15^{\circ}, 45^{\circ}\right]$} & Corr. coeff. & 0.81 & 0.79 & 0.76 & Corr. coeff. & 0.83 & 0.82 & 0.83 & Corr. coeff. & $0.68[0.74]$ & $0.70[0.75]$ & $0.69[0.70]$ \\
\hline & Slope & 0.96 & 0.79 & 0.73 & Slope & 1.39 & 1.18 & 1.19 & Slope & $0.80[0.84]$ & $0.72[0.75]$ & $0.72[0.76]$ \\
\hline & Intercept & 0.02 & 0.20 & 0.39 & Intercept & -0.70 & -0.37 & -0.37 & Intercept & $0.44[0.40]$ & $0.57[0.56]$ & $0.69[0.71]$ \\
\hline \multirow[t]{3}{*}{ Lat $\left[-15^{\circ}, 15^{\circ}\right]$} & Corr. coeff. & 0.92 & 0.90 & 0.89 & Corr. coeff. & 0.95 & 0.96 & 0.94 & Corr. coeff. & $0.89[0.90]$ & $0.79[0.81]$ & $0.85[0.85]$ \\
\hline & Slope & 0.86 & 0.82 & 0.86 & Slope & 1.70 & 1.84 & 1.75 & Slope & $0.91[0.89]$ & $0.85[0.82]$ & $0.91[0.90]$ \\
\hline & Intercept & 0.20 & 0.31 & 0.26 & Intercept & -1.32 & -1.56 & -1.35 & Intercept & $0.24[0.29]$ & $0.34[0.46]$ & $0.35[0.36]$ \\
\hline \multirow[t]{3}{*}{ Lat $\left[-45^{\circ},-15^{\circ}\right]$} & Corr. coeff. & 0.75 & 0.82 & 0.72 & Corr. coeff. & 0.89 & 0.90 & 0.80 & Corr. coeff. & $0.77[0.75]$ & $0.73[0.72]$ & $0.69[0.64]$ \\
\hline & Slope & 0.75 & 0.82 & 0.66 & Slope & 1.25 & 1.51 & 1.11 & Slope & $0.66[0.57]$ & $0.72[0.64]$ & $0.64[0.51]$ \\
\hline & Intercept & 0.20 & 0.15 & 0.42 & Intercept & -0.60 & -1.02 & -0.42 & Intercept & $0.50[0.64]$ & $0.36[0.51]$ & $0.47[0.60]$ \\
\hline
\end{tabular}

(vegetation fires). IASI and MOPITT distributions show very similar intensities for the African fires. IASI and AIRS have some problems with the inversion of spectra recorded above deserts in North Africa or in the Arabic Peninsula: high con- centrations are visible for IASI and the data were filtered for AIRS (in light grey, bottom left plot in Fig. 6). In fact, radiative transfer issues occur when processing the IASI data over very cold/icy and very hot/sandy surfaces. The local 


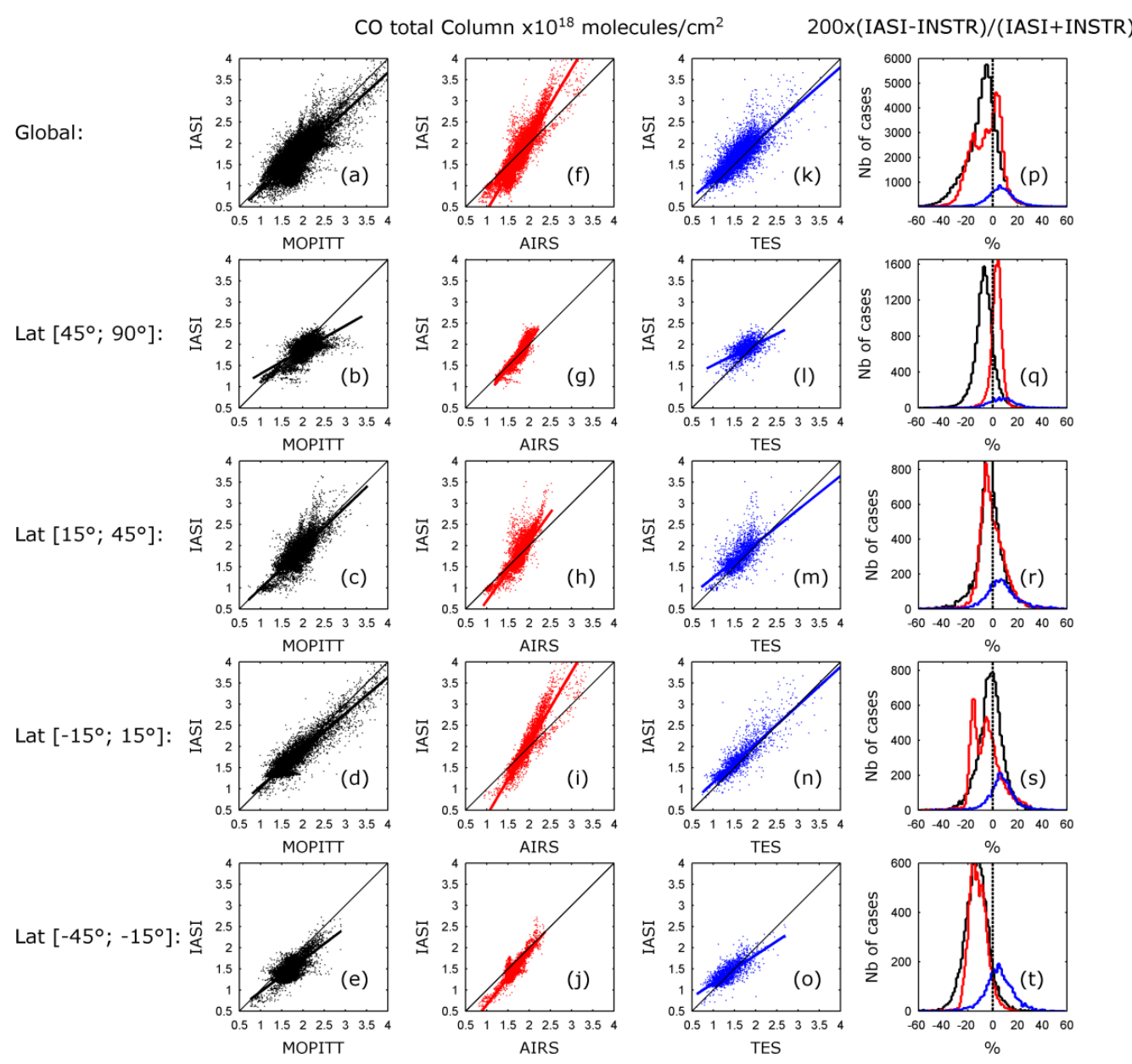

Fig. 7. Scatter plots between IASI and MOPITT, AIRS, TES, for August 2008, for different latitudes bands (see correlation coefficients in Table 2) and histograms of the differences in percent $(200 \times($ IASI-INSTR $) /(I A S I+I N S T R))$.

emissivity influences the sensitivity at the surface level and for the moment, emissivity data are not available from Eumetcast.

\subsubsection{IASI retrievals adjusted with MOPITT, AIRS or TES a priori}

The CO measurements are retrieved using different a priori assumptions and vertical resolutions so we should allow for the differing characteristics of the observing systems. In order to deal with the different a priori, we followed the method proposed by Rodgers and Connor (2003) and presented in more detail for TES and MOPITT comparisons in Luo et al. (2007a).

Here, the IASI columns have been adjusted according to the a priori used by MOPITT, AIRS or TES. To perform the comparison, monthly averaged data are binned in a $1^{\circ} \times 1^{\circ}$ grid, so for each point of the grid, the Eq. (3) is applied to the IASI mean retrieved CO profile to obtain the IASI adjusted profile and then the total column is derived:

$\boldsymbol{x}_{\text {adjusted }}^{\mathrm{IASI}}=\boldsymbol{x}_{\text {retrieved }}^{\mathrm{IASI}}+\left(\mathrm{A}^{\mathrm{IASI}}-\mathbf{I}\right)\left(\boldsymbol{x}_{\mathrm{a}}^{\mathrm{IASI}}-\boldsymbol{x}_{\mathrm{a}}^{\mathrm{INSTR}}\right)$

With $\boldsymbol{x}_{\text {adjusted }}^{\text {IASI }}$ the IASI profile adjusted to the INSTR (i.e. MOPITT, AIRS or TES) a priori, $x_{\text {retrieved }}^{\text {IASI }}$ the IASI retrieved profile, $\mathbf{A}^{\text {IASI }}$ the IASI averaging kernel matrix, $\boldsymbol{x}_{\mathrm{a}}^{\text {IASI }}$ and $\boldsymbol{x}_{\mathrm{a}}^{\mathrm{INSTR}}$ the a priori profile used for the IASI and the INSTR retrievals.

The two above-mentioned papers also recommend to smooth the $\mathrm{CO}$ profile of the instrument with the higher profiling capability with the averaging kernel functions of the instrument with the lowest vertical sensitivity. The equation to obtain the smoothed column is:

$\mathrm{x}_{\text {smoothed }}^{\text {high }}=\boldsymbol{a}^{\text {low }} \boldsymbol{x}_{\text {retrieved }}^{\text {high }}+\left(\boldsymbol{i}-\boldsymbol{a}^{\text {low }}\right) \boldsymbol{x}_{a}^{\text {low }}$

With $\mathrm{x}_{\text {smoothed }}^{\text {high }}$ the high resolution column smoothed by the averaging kernels of the low resolution instrument, $\boldsymbol{a}^{\text {low }}$ 
the low resolution instrument averaging kernel vector corresponding to the total column, $x_{\text {retrieved }}^{\text {high }}$ the high resolution retrieved profile and $x_{a}^{\text {low }}$ the low resolution a priori profile.

Some extended tests were performed to compare IASI and TES CO total columns using Eq. (4), in order to take the averaging kernel information into account. Because of TES's better spectral resolution, the TES CO profiles were smoothed by the IASI averaging kernel information. It is worth noting that even with a higher intrinsic vertical sensitivity TES can exhibit in some cases (e.g. see Fig. 5), depending on the geographic situation, a smaller DOFS than IASI because of the different a priori assumptions that lead to different averaging kernels and DOFS. As we lacked some of the averaging kernel information for other instruments, as the vertical resolutions are more similar, and as the impact on the coefficient correlations for TES-IASI was found to be limited (see Table 2, italic values), we restricted the application of Eq. (4) to TES. It is worth mentioning that this impact is limited because we compare integrated columns, and that it has a much larger impact when profiles are directly compared.

Figure 7 shows scatter plots of the averaged CO total columns $\left(1^{\circ} \times 1^{\circ}\right.$ gridded) for IASI as compared to MOPITT, AIRS and TES (without smoothing), for August 2008, for different latitude bands (Global $=\left[-90^{\circ} ; 90^{\circ}\right]$, $\left[45^{\circ} ; 90^{\circ}\right],\left[15^{\circ} ; 45^{\circ}\right],\left[-15^{\circ} ; 15^{\circ}\right]$ and $\left.\left[-45^{\circ} ;-15^{\circ}\right]\right)$. Also shown are the histograms of the relative differences in percent $(200 \times$ (IASI-INSTR)/(IASI+INSTR), with INSTR $=$ MOPITT, AIRS or TES) averaged the same way. Other periods/seasons have also been examined. Table 2 provides a summary of the correlation coefficients, the slope, and the intercept of the linear regression line, that were obtained from the analysis of August 2008, November 2008 and February 2009. As can be seen from Table 2, the correlation is generally good, although some biases are observed. For data averaged over all latitudes, the correlation coefficients averaged over the three months investigated are 0.87 (IASI/MOPITT), 0.92 (IASI/AIRS) and 0.84 (IASI/TES). This indicates that the four instruments can capture the dynamic range of the $\mathrm{CO}$ concentration with a good agreement. In the equatorial region (latitudes $\left[-15^{\circ} ; 15^{\circ}\right]$ ) MOPITT, AIRS and TES are very well correlated with IASI, with correlation coefficients of $0.90,0.95$ and 0.84 respectively. However MOPITT is higher than IASI with an average bias of $9.6 \%$ for data averaged over all latitudes $(11.4 \%$ for latitudes $\left[45^{\circ} ; 90^{\circ}\right]$ and $1.1 \%$ for latitudes $\left[-15^{\circ} ; 15^{\circ}\right]$ ) (see Fig. 7p, q and s for August 2008). This is consistent with a positive bias reported for MOPITT (V3 data) as shown in Emmons et al. (2009). AIRS shows a significant bias for the southern latitudes: $13.5 \%$ higher than IASI between $15^{\circ} \mathrm{S}$ and $45^{\circ} \mathrm{S}$ but is in close agreement with IASI between $45^{\circ} \mathrm{N}$ and $90^{\circ} \mathrm{N}$ (see Fig. 7t and q for August 2008). In other regions, AIRS CO data seems to be larger than IASI for weak concentrations but lower for high concentrations (Fig. 7f, $\mathrm{h}$ and $\mathrm{i}$ for August 2008) indicating a more restricted dy- namic range for AIRS retrievals due to the lower DOFS for AIRS CO as has been previously noted (Warner et al., 2007; Yurganov et al., 2008). On the contrary, TES is lower than IASI in all the latitude regions (6.2\%, see Fig. $7 p$ for August 2008).

\section{Summary and conclusions}

This paper presents a first assessment of the capabilities of IASI to measure $\mathrm{CO}$ on the global scale. The results presented here were obtained with the FORLI-CO algorithm, a near real time processing code that delivers atmospheric profiles of $\mathrm{CO}$ about four hours after the observation. Several months of observations have been analyzed, and both total column and coarse vertical profiles have been measured on the global scale, twice a day. CO quick-look distributions maps with different projections can be viewed from the LATMOS website at http://iasi-chem.aero.jussieu.fr. The vertical information available is strongly dependent on ground temperature, local emissivity and thermal contrast, with the daytime data being more useful for studying the atmospheric composition in the lowest parts of the atmosphere. Several radiative transfer issues remain when processing the IASI data over very cold/icy and very hot/sandy surfaces, as local emissivity data are not yet available from Eumetcast.

This paper compares the IASI CO total column global distribution, averaged over one month and for different seasons, with similar CO products provided by other space-borne instruments that also exploit the thermal infrared spectral range to sound the atmosphere. In the Northern Hemisphere and in the equatorial region, the comparisons show an agreement better than $\sim 7 \%$ between IASI and the three other IR sounders. In the Southern Hemisphere, under $15^{\circ} \mathrm{S}$, IASI is about $11 \%$ lower on average than MOPITT and AIRS. For large concentrations of $\mathrm{CO}$, such as in fire events for August 2008, IASI and MOPITT are in good agreement, but AIRS is systematically lower than IASI $(\sim 17 \%)$, likely due to the combination of AIRS coarser spectral resolution and larger retrieval footprint. TES shows a similar distribution structure but is slightly lower than IASI, for all latitudes bands. Further studies are needed to improve first guess a priori profiles, climatologies, statistics, and ancillary data. There is also a need to provide better knowledge of the Earth's surface temperature, local emissivity, atmospheric temperature and humidity profiles. Such improvements would improve the accuracy of CO satellite remote sensing retrievals, especially for nadir viewing thermal sounding instruments such as TES, AIRS, MOPITT and IASI.

Acknowledgements. IASI has been developed and built under the responsibility of the Centre National d'Etudes Spatiales (CNES, France). It is flown onboard the MetOp satellites as part of the Eumetsat Polar System. The IASI L1 data are received through the Eumetcast near real time data distribution service. IASI L1 and L2 data are stored in the Ether French atmospheric database 
(http://ether.ipsl.jussieu.fr). The research in France is conducted with the financial support of CNES. The research in Belgium was funded by the "Actions de Recherche Concertées" (Communauté Française), the Fonds National de la Recherche Scientifique (FRS-FNRS F.4511.08), the Belgian State Federal Office for Scientific, Technical and Cultural Affairs and the European Space Agency (ESA-Prodex C90-327). Analysis of TES measurements at NASA Langley Research Center is supported by NASA's Upper Atmospheric Chemistry and Modeling Program (ACMAP) and Upper Atmosphere Research Program (UARP). Analysis of AIRS CO retrievals is supported by the AIRS Project (JPL) and NASA's Tropospheric Chemistry Program. The authors are grateful to INSU for publication support.

Edited by: A. Richter

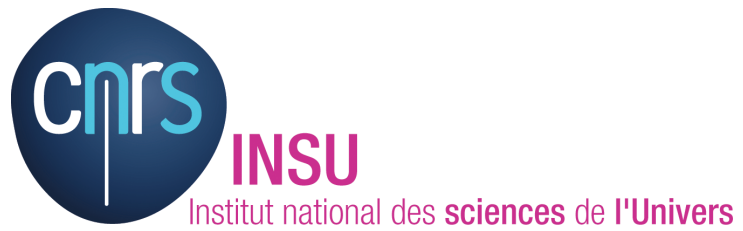

The publication of this article is financed by CNRS-INSU.

\section{References}

Aumann, H. H., Chahine, M. T., Gautier, C., Goldberg, M . D., Kalnay, E., McMillin, L., M., Revercomb, H., Rosenkranz, P. W., Smith, W. L., Staelin, D. H., Strow, L. L., and Susskind, J.: AIRS/AMSU/HSB on the Aqua mission: Design, science objectives, data products, and processing systems, IEEE T. Geosci. Remote Sens., 41, 2, 253-264, 2003.

Barret, B., Hurtmans, D., Carleer, M., Mazière, M. D., Mahieu, E., and Coheur, P.-F.: Line narrowing effect on the retrieval of HF and HCL vertical profiles from ground-based FTIR measurements, J. Quant. Spectrosc. Rad., 95, 499-519, 2005.

Barret, B., Ricaud, P., Santee, M. L., Attie, J.-L., Urban, J., Le Flochmoen, E., Berthet, G., Murtagh, D., Eriksson, P., Jones, A., De La Noë, J., Dupuy, E., Froidevaux, L., Livesey, N. J., Waters, J. W., and Filipiak, M. J.: Intercomparisons of trace gases profiles from the Odin/SMR and Aura/MLS limb sounders, J. Geophys. Res., 111, D21302, doi:10.1029/2006JD007305, 2006.

Beer, R.: TES on the Aura mission: scientific objectives, measurements, and analysis overview, IEEE T. Geosci. Remote Sens., 44, 1102-1105, 2006.

Brasseur, G., Hauglustaine, D., Walters, S., Rasch, R., Müller, J.-F., Granier, C., and Tie, X.: MOZART, a global chemical transport model for ozone and related chemical tracers 1. Model description, J. Geophys. Res., 103(D21), 28265-28289, 1998.

Buchwitz, M., de Beek, R., Bramstedt, K., et al.: Global carbon monoxide as retrieved from SCIAMACHY by WFM-DOAS, Atmos. Chem. Phys., 4, 1945-1960, 2004,

http://www.atmos-chem-phys.net/4/1945/2004/.

Buchwitz, M., Khlystova, I., Bovensmann, H., and Burrows, J. P.: Three years of global carbon monoxide from SCIAMACHY: comparison with MOPITT and first results related to the detec- tion of enhanced CO over cities, Atmos. Chem. Phys., 7, 2399 2411, 2007, http://www.atmos-chem-phys.net/7/2399/2007/.

Bowman, K. W., Rodgers, C. D., Kulawik, S. S., Worden, J., Sarkissian, E., Osterman, G., Steck, T., Ming Lou, Eldering, A., Shephard, M., Worden, H., Lampel, M., Clough, S., Brown, P., Rinsland, C., Gunson, M., and Beer, R.: Tropospheric Emission Spectrometer: Retrieval method and error analysis, IEEE T. Geosci. Remote Sens., 44, 1297-1307, 2006.

Boynard, A., Clerbaux, C., Coheur, P.-F., Hurtmans, D., Turquety, S., George, M., Hadji-Lazaro, J., Keim, C., and Mayer-Arnek, J.: Measurements of total and tropospheric ozone from the IASI instrument: comparison with satellite and ozonesonde observations, Atmos. Chem. Phys., 9, 6255-6271, 2009.

Clarisse, L., Coheur, P.-F., Prata, A. J., Hurtmans, D., Razavi, A., Phulpin, T., Hadji-Lazaro, J., and Clerbaux, C.: Tracking and quantifying volcanic $\mathrm{SO}_{2}$ with IASI, the September 2007 eruption at Jebel at Tair, Atmos. Chem. Phys., 8, 7723-7734, 2008, http://www.atmos-chem-phys.net/8/7723/2008/.

Clerbaux, C., Hadji-Lazaro, J., Payan, S., Camy-Peyret, C., Wang, J., Edwards, D., and Luo, M., Retrieval of CO from nadir remotesensing measurements in the infrared by use of four different inversion algorithms, Appl. Opt., 41, 33, 7068-7078, 2002.

Clerbaux, C., Coheur, P.-F., Hurtmans, D., Barret, B., Carleer, M., Colin, R., Semeniuk, K., McConnell, J. C., Boone, C., and Bernath, P.: Carbon monoxide distribution from the ACEFTS solar occultation measurements, Geophys. Res. Lett., 32, L16S01, doi10.1029/2005GL022394, 2005.

Clerbaux, C., Hadji-Lazaro, J., Turquety, S., George, M., Coheur, P.-F., Hurtmans, D., Wespes, C., Herbin, H., Blumstein, D., Tournier, B., and Phulpin, T.: The IASI/MetOp mission: first observations and highlight of its potential contribution to the GMES Earth observation component, Space Research Today (COSPAR Inf. Bull.), 168, 19-24, 2007.

Clerbaux, C., George, M., Turquety, S., Walker, K. A., Barret, B., Bernath, P., Boone, C., Borsdorff, T., Cammas, J. P., Catoire, V., Coffey, M., Coheur, P.-F., Deeter, M., De Mazière, M., Drummond, J., Duchatelet, P., Dupuy, E., de Zafra, R., Eddounia, F., Edwards, D. P., Emmons, L., Funke, B., Gille, J., Griffith, D. W. T., Hannigan, J., Hase, F., Höpfner, M., Jones, N., Kagawa, A., Kasai, Y., Kramer, I., Le Flochmoën, E., Livesey, N. J., López-Puertas, M., Luo, M., Mahieu, E., Murtagh, D., Nédélec, P., Pazmino, A., Pumphrey, H., Ricaud, P., Rinsland, C. P., Robert, C., Schneider, M., Senten, C., Stiller, G., Strandberg, A., Strong, K., Sussmann, R., Thouret, V., Urban, J., and Wiacek, A.: CO measurements from the ACE-FTS satellite instrument: data analysis and validation using ground-based, airborne and spaceborne observations, Atmos. Chem. Phys., 8, 2569-2594, 2008a,

http://www.atmos-chem-phys.net/8/2569/2008/.

Clerbaux, C., Edwards, D. P., Deeter, M., Emmons, L., Lamarque, J.-F., Tie, X. X., Massie, S. T., and Gille, J.: Carbon monoxide pollution from cities and urban areas observed by the Terra/MOPITT mission, Geophys. Res. Lett, 35, L03817, doi:10.1029/2007GL032300, 2008b.

Clerbaux, C., Boynard, A., Clarisse, L., George, M., Hadji-Lazaro, J., Hurtmans, D., Herbin, H., Pommier, M., Razavi, A., Turquety, S., Wespes, C., and Coheur, P.-F.: Monitoring of atmospheric composition using the thermal infrared IASI/METOP sounder, Atmos. Chem. Phys., 9, 6041-6054, 2009, 
http://www.atmos-chem-phys.net/9/6041/2009/.

Coheur, P.-F., Barret, B., Turquety, S., Hurtmans, D., Hadji-Lazaro, J., and Clerbaux, C.: Retrieval and characterization of ozone vertical profiles from a thermal infrared nadir sounder, J. Geophys. Res., 110, D24303, doi:10.1029/2005JD005845, 2005.

Coheur, P.-F., Clarisse, L., Turquety, S., Hurtmans, D., and Clerbaux, C.: IASI measurements of reactive trace species in biomass burning plumes, Atmos. Chem. Phys., 9, 5655-5667, 2009, http://www.atmos-chem-phys.net/9/5655/2009/.

Comer, M. M.: Retrieving Carbon Monoxide Abundances from the Atmospheric Infrared Sounder (AIRS), Ph.D. Dissertation, University of Maryland Baltimore County, USA, 2006.

Deeter, M. N., Emmons, L. K., Francis, G. L., Edwards, D. P., Gille, J. C., Warner, J. X., Khattatov, B., Ziskin, D., Lamarque, J.-F., Ho, S.-P., Yudin, V., Attié, J.-L., Packman, D., Chen, J., Mao, D., and Drummond, J. R.: Operational carbon monoxide retrieval algorithm and selected results for the MOPITT instrument, J. Geophys. Res., 108(D14), 4399, doi:10.1029/2002JD003186, 2003.

Deeter, M. N., Edwards, D. P., Gille, J. C., and Drummond, J. R.: Sensitivity of MOPITT observations to carbon monoxide in the lower troposphere, J. Geophys. Res., 112, D24306, doi:10.1029/2007JD008929, 2007.

Deeter, M. N., Edwards, D. P., Gille, J. C., and Drummond, J. R.: CO retrievals based on MOPITT near-infrared observations, J. Geophys. Res., 114, D04303, doi:10.1029/2008JD010872, 2009.

de Laat, A. T. J., Gloudemans, A. M. S., Schrijver, H., van den Broek, M. M. P., Meirink, J. F., Aben, I., and Krol, M.: Quantitative analysis of SCIAMACHY carbon monoxide total column measurements, Geophys. Res. Lett., 33, L07807, doi:10.1029/2005GL025530, 2006.

de Laat, A. T. J., Gloudemans, A. M. S., Aben, I., Krol, M., Meirink, J. F., van der Werf, G. R., and Schrijver, H.: SCIAMACHY carbon monoxide total columns: statistical evaluation and comparison with CTM results, J. Geophys. Res., 112, D12310, doi:10.1029/2006JD008256, 2007.

Drummond, J. R.: Novel correlation radiometer: the lengthmodulated radiometer, Appl. Opt., 28, 2451-2452, 1989.

Duncan, B. N. and Logan, J. A.: Model analysis of the factors regulating the trends and variability of carbon monoxide between 1988 and 1997, Atmos. Chem. Phys., 8, 7389-7403, 2008, http://www.atmos-chem-phys.net/8/7389/2008/.

Edwards, D. P., Emmons, L. K., Hauglustaine, D. A., Chu, A., Gille, J. C., Kaufman, Y. J., Pétron, G., Yurganov, L. N., Giglio, L., Deeter, M. N., Yudin, V., Ziskin, D. C., Warner, J., Lamarque, J.F., Francis, G. L., Ho, S. P., Mao, D., Chan, J., and Drummond, J. R.: Observations of Carbon Monoxide and Aerosol From the Terra Satellite: Northern Hemisphere Variability, J. Geophys. Res., 109, D24202, doi:10.1029/2004JD0047272004, 2004.

Emmons, L. K., Deeteret, M. N., Gille, J. C., al.: Validation of Measurements of Pollution in the Troposphere (MOPITT) CO retrievals with aircraft in situ profiles, J. Geophys. Res., 109, D03309, doi:10.1029/2003JD004101, 2004.

Emmons, L. K., Pfister, G. G., Edwards, D. P., Gille, J. C., Sachse, G., Blake, D., Wofsy, S., Gerbig, C., Matross, D., and Nédélec, P.: Measurements of Pollution in the Troposphere (MOPITT) validation exercises during summer 2004 field campaigns over North America, J. Geophys. Res., 112, D12S02, doi:10.1029/2006JD007833, 2007.

Emmons, L. K., Edwards, D. P., Deeter, M. N., Gille, J. C., Cam- pos, T., Nédélec, P., Novelli, P., and Sachse, G.: Measurements of Pollution In The Troposphere (MOPITT) validation through 2006, Atmos. Chem. Phys., 9, 1795-1803, 2009,

http://www.atmos-chem-phys.net/9/1795/2009/.

Frankenberg, C., Platt, U., and Wagner, T.: Retrieval of CO from SCIAMACHY onboard ENVISAT: detection of strongly polluted areas and seasonal patterns in global $\mathrm{CO}$ abundances, Atmos. Chem. Phys., 5, 1639-1644, 2005,

http://www.atmos-chem-phys.net/5/1639/2005/.

Funke, B., López-Puertas, M., Bermejo-Pantaleón, D., von Clarmann, T., Stiller, G. P., Höpfner, M., Grabowski, U., and Kaufmann M.: Analysis of nonlocal thermodynamic equilibrium $\mathrm{CO} 4.7 \mu \mathrm{m}$ fundamental, isotopic, and hot band emissions measured by the Michelson Interferometer for Passive Atmospheric Sounding on Envisat, J. Geophys. Res., 112, D11305, doi:10.1029/2006JD007933, 2007.

Hurtmans, D. et al.: FORLI: A Fast Operational Retrieval on Layers code for IASI, in preparation, 2009.

Kulawik, S. S., Bowman, K. W., Luo, M., Rodgers, C. D., and Jourdain, L.: Impact of nonlinearity on changing the a priori of trace gas profile estimates from the Tropospheric Emission Spectrometer (TES), Atmos. Chem. Phys., 8, 3081-3092, 2008, http://www.atmos-chem-phys.net/8/3081/2008/.

Kurylo, M.: Network for the detection of stratospheric change (NDSC), in Remote sensing of atmospheric chemistry; Proceedings of the Meeting, Orlando, FL, April 1-3, A93-31376 11-35, 168-174, 1991.

Livesey, N. J., Filipiak, M. J., Froidevaux, L., et al.: Validation of Aura Microwave Limb Sounder O3 and CO observations in the upper troposphere and lower stratosphere, J. Geophys. Res., 113, D15S02, doi:10.1029/2007JD008805, 2008.

Logan, J., Prather, M. J., Wofsy, S. C., and McElroy, M. B.: Tropospheric chemistry: A global perspective, J. Geophys. Res., 86, 7210-7254, 1981.

Luo, M., Rinsland, C. P, Rodgers, C. D., Logan, J. A., Worden, H., Kulawik, S., Eldering, A., Goldman, A., Shephard, M. W., Gunson, M., and Lampel, M.: Comparison of carbon monoxide measurements by TES and MOPITT: Influence of a priori data and instrument characteristics on nadir atmospheric species retrievals, J. Geophys. Res., 112, D09303, doi:10.1029/2006JD007663, 2007a.

Luo, M., Rinsland, C., Fisher, B., Sachse, G., Diskin, G., Logan, J., Worden, H., Kulawik, S., Osterman, G., Eldering, A., Herman, R., and Shephard, M.: TES carbon monoxide validation with DACOM aircraft measurements during INTEX-B 2006, J. Geophys. Res., 112, D24S48, doi:10.1029/2007JD008803, $2007 \mathrm{~b}$.

McMillan, W. W., Barnet, C., Strow, L., Chahine, M. T., McCourt, M. L., Warner, J. X., Novelli, P. C., Korontzi, S., Maddy, E. S., and Datta, S.: Daily global maps of carbon monoxide from NASA's Atmospheric Infrared Sounder, Geophys. Res. Lett., 32, L11801, doi:10.1029/2004GL021821, 2005.

McMillan, W. W., Warner, J. X., Comer, M. M., Maddy, E., Chu, A., Sparling, L., Eloranta, E. W., Hoff, R. M., Sachse, G., Barnet, C., Razenkov, I. A., and Wolf, W.:AIRS views of transport from 12-22 July 2004 Alaskan/Canadian fires: Correlation of AIRS CO and MODIS AOD with forward trajectories and comparison of AIRS CO retrievals with DC-8 in situ measurements during INTEX-A/ICARTT, J. Geophys. Res., 113, D20301, doi:10.1029/2007JD009711, 2008. 
Nedelec, P., Cammas, J. P., Thouret, V., Athier, G., Cousin, J. M., Legrand, C., Abonnel, C., Lecoeur, F., Cayez, G., and Marizy, C.: An improved infra-red carbon monoxide analyser for routine measurements aboard commercial Airbus aircraft: Technical validation and first scientific results of the MOZAIC III program, Atmos. Chem. Phys., 3, 1551-1564, 2003, http://www.atmos-chem-phys.net/3/1551/2003/.

Nedelec, P., Thouret, V., Brioude, J., Sauvage, B., Cammas, J.-P., and Stohl, A.: Extreme CO concentrations in the upper troposphere over northeast Asia in June 2003 from the in situ MOZAIC aircraft data, Geophys. Res. Lett., 32, L14807, doi:10.1029/2005GL023141, 2005.

Novelli, P., Masarie, K., and Lang, P.: Distributions and recent changes of carbon monoxide in the lower troposphere, J. Geophys. Res., 103, D15, 19015-19033, 1998.

Osterman, G., Bowman, K., Eldering, A., et al.: TES Level 2 Data User's Guide, v3.1, JPL D-38042, 31 July, 2008.

Pan, L., Gille, J., Edwards, D., Bailey, P., and Rodgers, C.: Retrieval of tropospheric carbon monoxide for the MOPITT experiment, J. Geophys. Res., 103(D24), 32277-32290, 1998.

Pougachev, N. S. and Rinsland, C. P.: Spectroscopic study of the seasonal variation of carbon monoxide vertical distribution above Kitt Peak, J. Geophys. Res., 100, 1409-1416, 1995.

Pougatchev, N., August, T., Calbet, X., Hultberg, T., Oduleye, O., Schlüssel, P., Stiller, B., Germain, K. S., and Bingham, G.: IASI temperature and water vapor retrievals - error assessment and validation, Atmos. Chem. Phys., 9, 6453-6458, 2009, http://www.atmos-chem-phys.net/9/6453/2009/.

Pumphrey, H. C., Filipiak, M. J., Livesey, N. J., Schwartz, M. J., Boone, C., Walker, K. A., Bernath, P., Ricaud, P., Barret, B., Clerbaux, C., Jarnot, R. F., Manney, G. L., and Waters, J. W.: Validation of middle-atmosphere carbon monoxide retrievals from Microwave Limb Sounder on Aura, J. Geophys. Res., 112, D24S38, doi:10.1029/2007JD008723, 2007.

Razavi, A., Clerbaux, C., Wespes, C., Clarisse, L., Hurtmans, D., Payan, S., Camy-Peyret, C., and Coheur, P.-F.: Characterization of methane retrievals from the IASI space-borne sounder, Atmos. Chem. Phys., 9, 7889-7899, 2009.

Rinsland, C. P., Luo, M., Logan, J. A., Beer, R., Worden, H., Kulawik, S. S., Rider, D., Osterman, G., Gunson, M., Eldering, A., Goldman, A., Shephard, M., Clough, S. A., Rodgers, C., Lampel, M., and Chiou, L.: Nadir measurements of carbon monoxide (CO) distributions by the tropospheric emission spectrometer instrument onboard the Aura spacecraft: Overview of analysis approach and examples of initial results, Geophys. Res. Lett., 33, L22806, doi:10.1029/2006GL027000, 2006.

Rinsland, C.P., Luo, M., Shephard, M. W., Clerbaux, C., Boone, C. D., Bernath, P. F., Chiou, L., and Coheur, P. F.: Tropospheric emission spectrometer (TES) and atmospheric chemistry experiment (ACE) measurements of tropospheric chemistry in tropical southeast Asia during a moderate El Niño in 2006, J. Quant. Spectrosc. Rad., 109, 1931-1942, doi:10.1016/j.jqsrt.2007.12.020, 2008.

Rodgers, C. D.: Inverse methods for atmospheric sounding : theory and practice, Ser. Atmos. Oceanic Planet. Phys., 2, World Sci., Hackensack, N. J., 2000.

Rodgers, C. D. and B. J. Connor, Intercomparison of remote sounding instruments, J. Geophys. Res., 108(D3), 4116, doi:10.1029/2002JD002299, 2003.
Schluessel, P., Hultberg, T. H., Phillips, P. L. T., August, T., and Calbet, X.: The operational IASI Level 2 processor, Adv. Space Res., 36, 982, 2005.

Susskind, J., Barnet, C. D., and Blaisdell, J. M.: Retrieval of atmospheric and surface parameters form AIRS/AMSU/HSB data in the presence of clouds, IEEE T. Geosci. Remote Sens., 41, 390-409, 2003.

Turquety, S., Hadji-Lazaro, J., Clerbaux, C., Hauglustaine, D. A., Clough, S. A., Cassé, V., Schlüssel, P., and Mégie, G.: Operational trace gas retrieval algorithm for the Infrared Atmospheric Sounding Interferometer, J. Geophys. Res., 109, D21301, doi:10.1029/2004JD004821, 2004.

Turquety, S., Clerbaux, C., Law, K., Coheur, P.-F, Cozic, A., Szopa, S., Hauglustaine, D., Hadji-Lazaro, J., Gloudemans, A., Schrijver, H., Boone, C. D., Bernath, P. F., and Edwards, D.: Analysis of $\mathrm{CO}$ transport from Asia using nadir (MOPITT, SCIAMACHY) and solar occultation (ACE-FTS) satellite measurements with global modelling, Atmos. Chem. Phys., 8, 51875204, 2008, http://www.atmos-chem-phys.net/8/5187/2008/.

Turquety, S., Hurtmans, D., Hadji-Lazaro, J., Coheur, P.-F., Clerbaux, C., Josset, and D., Tsamalis, C.: Tracking the emission and transport of pollution from wildfires using the IASI CO retrievals: analysis of the summer 2007 Greek fires, Atmos. Chem. Phys., 9, 4897-4913, 2009,

http://www.atmos-chem-phys.net/9/4897/2009/.

Velazco, V., Wood, S. W., Sinnhuber, M., Kramer, I., Jones, N. B., Kasai, Y., Notholt, J., Warneke, T., Blumenstock, T., Hase, F., Murcray, F. J., and Schrems, O.: Annual variation and global distribution of strato-mesospheric carbon monoxide measured by ground-based Fourier transform infrared spectroscopy, Atmos. Chem. Phys., 7, 1305-1312, 2007,

http://www.atmos-chem-phys.net/7/1305/2007/.

Warner, J., McCourt Comer, M., Barnet, C. D., McMillan, W. W., Wolf, W., Maddy, E., and Sachse, G.: A comparison of satellite tropospheric carbon monoxide measurements from AIRS and MOPITT during INTEX-A, J. Geophys. Res., 112, D12S17, doi:10.1029/2006JD007925, 2007.

Wespes, C., Hurtmans, D., Clerbaux, C., Santee, M. L., Martin, R. V., and Coheur, P.-F.: Global distributions of nitric acid from IASI/MetOP measurements, Atmos. Chem. Phys., 9, 79497962, 2009.

Worden, H., Beer, R., Bowman, K. W., Fisher, B., Luo, M., Rider, D., Sarkissian, E., Tremblay, D., and Zong, J.: TES Level 1 Algorithms: Interferogram Processing, Geolocation, Radiometric, and Spectral Calibration, IEEE T. Geosci. Remote Sens., 44, 1288-1296, 2006.

Yurganov, L. N., Blumenstock, T., Grechko, E. I., Hase, F., Hyer, E. J., Kasischke, E. S., Koike, M., Kondo, Y., Kramer, I., Leung, F.-Y., Mahieu, E., Mellqvist, J., Notholt, J., Novelli, P. C., Rinsland, C. P., Scheel, H. E., Schulz, A., Strandberg, A., Sussmann, R., Tanimoto, H., Velazco, V., Zander, R., and Zhao, Y.: A quantitative assessment of the 1998 carbon monoxide emission anomaly in the Northern Hemisphere based on total column and surface concentration measurements, J. Geophys. Res., 109, D15305, doi:10.1029/2004JD004559, 2004.

Yurganov, L. N., Duchatelet, P., Dzhola, A. V., Edwards, D. P., Hase, F., Kramer, I., Mahieu, E., Mellqvist, J., Notholt, J., Novelli, P. C., Scheel, H.-E., Schneider, M., Schulz, A., Strandberg, A., Sussmann, R., Tanimoto, H., Velazko, V., Drummond, J. R., 
and Gille, J. C.: Increased Northern Hemispheric CO burden in the troposphere in 2002 and 2003 detected from the ground and from a satellite, Atmos. Chem. Phys., 5, 563-573, 2005, http://www.atmos-chem-phys.net/5/563/2005/.

Yurganov, L. N., McMillan, W. W., Dzhola, A. V., Grechko, E. I., Jones, N. B., and van der Werf, G. R.: Global AIRS and MOPITT CO measurements: Validation, comparison, and links to biomass burning variations and carbon cycle, J. Geophys. Res., 113, D09301, doi:10.1029/2007JD009229, 2008.
Zander, R., Mahieu, E., Demoulin, P., Duchatelet, P., Roland, R., Servais, C., De Mazière, M., Reimann, S., and Rinsland, C. P.: Our changing atmosphere: Evidence based on long-term infrared solar observations at the Jungfraujoch since 1950, Sci. Total Environ., 391, 184-195, doi:10.1016/j.scitotenv.2007.10.018, 2008.

Zhou, D. K., Smith, W. L., Larar, A. M., Liu, X., Taylor, J. P., Schlüssel, P., Strow, L. L., and Mango, S. A.: All weather IASI single field-of-view retrievals: case study - validation with JAIVEx data, Atmos. Chem. Phys., 9, 2241-2255, 2009. 